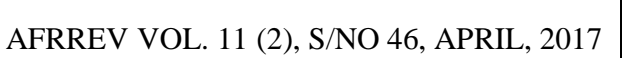 \\ 160 \\ African Research Review
}

AN INTERNATIONAL MULTI-DISCIPLINARY JOURNAL, ETHIOPIA

AFRREV VOL. 11 (2), SERIAL NO. 46, APRIL, 2017: 160-177

ISSN 1994-9057 (Print) ISSN 2070-0083 (Online)

DOI : http://dx.doi.org/10.4314/afrrev.v11i2.12

\section{An Examination of the Relationship between Financial Development and Economic Growth in Nigeria: Application of Multivariate Var Framework}

\author{
Ndubuisi, Paul \\ Department of Banking and Finance \\ Abia State, University, Uturu \\ Abia State, Nigeria \\ E-mail: pauloabsu2017@gmail.com
}

\begin{abstract}
This study examined the relationship between financial development and economic growth in Nigeria using annual data for the period 1981-2014. The study employed multivariate VAR framework approach to co-integration to evaluate the long-run relationships between financial development and economic growth. Three financial indicators were used: deposit money bank assets as percentage GDP, ratio of liquid liabilities to GDP and ratio of private sector credit of deposit money banks to GDP. The result found that real gdpc and financial development variables have at least one common stochastic trend driving their relationship. Through VECM granger causality framework, the result found that there is long run unidirectional causality running from economic growth to liquid liability and deposit money bank assets while deposit money bank assets have little significant influence on real gdpc especially at long run. We found feedback effect between private sector credit of deposit money banks and economic growth at the long run. The findings in this study have some important policy implication. To promote the financial system and at the same time promote economic growth, monetary authorities must ensure that banks provide necessary funds to the real sector of the economy.
\end{abstract}

Copyright $\odot$ International Association of African Researchers and Reviewers, 2006-2017: www. afrrevjo.net.

Indexed African Journals Online: www.ajol.info 
Key Words: financial development, economic growth, liquid liability, causality, vector error correction

\section{Introduction}

The relationship between financial development and economic growth has long been established both at theoretical and empirical levels. However, the emergence of new theories of endogenous growth has indeed renewed interest in the potential role of financial systems in promoting economic growth and development. Greenwood and Jovanovich (1990), Pagano (1993) and King and Levine (1993) had all shown in their studies that financial development does have a positive impact on economic growth through investment, saving, productivity of capital and effective management of information.

There are strands of literature in the study of financial development and economic growth especially in time series studies in the direction of causality. Patrick (1966) explained that finance can lead to economic growth through what he termed the "supply-leading" hypothesis; and equally that economic growth can also stimulate financial development - he called this the "demand following" hypothesis. Ever since the formulation of these hypotheses, empirical conclusions on the direction of causality between financial development and economic growth have remained inconclusive.

In recent years there has been an increase in the application of multivariate VAR model to time-series studies on financial development and economic growth. Prominent among these include Luintel and Khan (1999), Chang and Caudill (2005), Liang and Teng (2006), Ang and Mckibbin (2007), Abu-Badr and Abu-Qarn (2008), Masih et al. (2009), Gries et al. (2009), and Wolde-Rafael (2009). This is because the endogenous growth models have explained that the interaction between financial development and growth often occurs through a number of channels for example through investment, productivity and savings. Therefore, recent empirical works are now exploring some of these channels through the application of multivariate VAR methodology. However, this has still not resolved the issue of causality between financial development and economic growth.

Based on the above, the current study made testable hypothesis that was empirically carried out in the course of this study.

1. Ho: $\beta=0$ - There is no long-run significant relationship between economic growth and the financial development indicators (proxied by liquid liability, deposit money bank assets, private sector credit of deposit money banks)

2. Ho: $\beta=0$ - There is no causal significant relationship between the economic growth and liquid liability in Nigeria

Copyright $($ I) International Association of African Researchers and Reviewers, 2006-2017: www.afrrevjo.net.

Indexed African Journals Online: www.ajol.info 
3. Ho: $\beta=0$ - There is no causal significant relationship between deposit money bank assets and economic growth in Nigeria

4. Ho: $\beta=0$-There is no causal significant relationship between the private sector credit of deposit money banks and economic growth in Nigeria

\section{Theoretical Framework: Financial Development and Economic Growth}

There is a growing literature on the impact of financial development on economic growth of the Nigerian economy as a result of the increasing growth in the financial system. According to financial development literature: Patrick (1966), Gurley and Shaw (1955), Goldsmith (1969), Hicks (1969), McKinnon (1973) and Shaw (1973) there is causation that runs from financial development to economic growth implying that financial markets and institutions will increase the financial services. This will definitely lead to high but sustainable real economic growth. Prior to then the relationship between financial development and economic growth has caught the attention of economist such as Schumpeter (1911) who argued that the services provided by financial intermediaries such as mobilizing savings, evaluating projects, managing risk, monitoring managers and facilitating transaction are essential for the technological innovation and economic development of a nation; although the channel and even the direction of causality have remained unresolved in both theory and empirical discuss.

At the forefront of these studies are these researchers: Gurley and Shaw (1955), Goldsmith (1969) and Hicks (1969) who argued that development of a financial system is crucial in stimulating economic growth and under-developed financial systems retard economic growth hence policies aimed at expanding the financial system should be formulated in order to foster growth. McKinnon (1973) and Shaw (1973) have also emphasized on the role of financial intermediaries and financial markets in the growth process. The McKinnon model assumes that investment in a typical developing economy is mostly self-financed hence given its lumpy nature, investment cannot materialize unless sufficient saving is accumulated in the form of bank deposits (McKinnon, 1973). Also, Shaw (1973) further argued that financial intermediaries promote investment and raise output growth through borrowing and lending. This is achieved through mobilization of resources from surplus economic units to deficit economic units. In doing this, they evolved appropriate structures necessary for the intermediation functions which they perform. The result of such financial liberalization, Ang (2007) argued, will lead to increased output growth.

\section{Studies on Financial Development and Economic Growth in Nigeria}

Several empirical studies have been carried out to examine the impact of financial development in Nigeria and other developing countries with the ultimate objectives of prescribing measures to enhance financing. Some of the studies will be reviewed,

Copyright () International Association of African Researchers and Reviewers, 2006-2017:

$$
\text { www.afrevjo.net. }
$$

Indexed African Journals Online: www.ajol.info 
particularly those with some relevance to Nigeria. Azege (2004) examined the empirical relationship between the level of development by financial intermediaries and growth. The study employed data on aggregate deposit money bank credit over time and gross domestic product to establish that a moderate positive relationship exists between financial development and economic growth. He concluded that the development of financial intermediary institutions in Nigeria is fundamental for overall economic growth.

Nzotta and Okereke (2009) examined financial development and economic development in Nigeria between 1986 and 2007. The study made use of time series data and two stages least squares analytical framework and found that four of the nine variables; lending rates, financial savings ratio, cheques/GDP ratio and the deposit money banks/GDP ratio had a significant relationship with financial development and concluded that the financial system has not sustained an effective financial intermediation, especially credit allocation and a high level of monetization of the economy.

\section{Empirical Evidence from Advanced and Emerging Market}

Various academic researchers have examined and documented the link between finance and economic growth in varying dimensions. For example, Wadud (2005) examined the long-run causal relationship between financial development and economic growth for 3 South Asian countries namely India, Pakistan and Bangladesh. The study employed a co-integrated vector autoregressive model to assess the long-run relationship between financial development and economic growth. The results indicate causality between financial development and economic growth but running from financial development to economic growth.

Waqabaca (2004) examined the causal relationship between financial development and growth in Fiji using low frequency data from 1970 to 2000. The study employed unit root test and co integration technique within a vicariate VAR framework. Empirical results suggest a positive relationship between financial development and economic growth for Fiji with causality running from economic growth to financial development. He posited that this outcome is common with countries that have less sophisticated financial systems.

Arestis and Demetriades (1977), using Johansen co-integration on time series analysis for the United states and Germany found insufficient evidence to claim that financial development spurs economic growth. Their analyzed data rather pointed to the direction that real GDP contributes to both banking system and stock market development.

Odiambho (2001) investigated the finance-growth nexus in South Africa using cointegration approach and vector error correction model on monetization ratio; namely

Copyright (C) International Association of African Researchers and Reviewers, 2006-2017: www.afrrevjo.net.

Indexed African Journals Online: www.ajol.info 
the ratio of M2 to GDP and intermediation ratio, the ratio of bank claims on the private sector to GDP against economic growth proxied by real GDP per capital. Their results revealed demand following response between financial development and economic growth and totally discredited the supply leading hypothesis.

Guryay et al (2007), examined the relationship between financial development and economic growth for Northern Cyprus for the period 1986 - 2004 and concluded that there was a negligible positive effect of financial development on economic growth of Northern Cyprus. Rather, the analysis shows that there was evidence of causality from economic growth to the development of financial intermediaries. (King and Levine, 1993 and Levine, Zervos, 1998). Rajan and zingales (1908) using time series analysis (1980-1990) found that financial development has a strong effect on economic growth. Also thngevelu et al, (2004) time series analysis for Australia study represents evidences that financial, markets have causal effect on growth.

Murinde and Eng (1991), Luintel and Khan (1999) argued that a number of endogenous growth models show a two-way relationship financial development and economic growth (Kar and Pentecost 2000). Rousseau and Wachtel (200f) re-examined the core cross country panel result and found that the impact of financial depending on growth is not as strong with more recent data as.it appeared in the original panel studies with data for the period from 1960-19891 and suggested that financial development has a positive effect on growth if not done to excess. Altay and Atgur (2010) advocated bidirectional causality hypothesis. In this study, financial development and economic growth relationship - using VAR Model approach were investigated in Turkey over the period 1970-2006. His empirical findings showed that there was a bidirectional Granger causality relationship between financial development and economic growth in Turkey.

Bailey (2002), studying the relationship between financial sector and economic growth in transition countries was of the view that increased competition in the banking sector (which leads to higher deposit and lower loan rate) has not caused economic growth in Spain province. Stern listed several topics omitted from the survey that are worthy of future research, and financial development was not even mentioned on that list. Future neglect of the role of financial development in economic development is also found in Myers and Seers (1984) book, which is a collection of essays by pioneers of development economics.

\section{Data Description and Methodology}

\section{Data Description}

This study used annual data covering the period from 1981 to 2014 to investigate the impact of financial development on economic growth.

Copyright (C) International Association of African Researchers and Reviewers, 2006-2017: www.afrrevjo.net.

Indexed African Journals Online: www.ajol.info 
Table 1: List of variables and explanations

\begin{tabular}{|c|c|c|c|}
\hline VARIABLES & YEAR & $\begin{array}{|lll|}\text { EXPLANATION } & \& & \text { APRIORI } \\
\text { EXPECTIONS } & & \end{array}$ & SOURCE \\
\hline $\begin{array}{l}\text { Liquid Liability as } \\
\text { a percentage of } \\
\text { GDP (llgdp) }\end{array}$ & 1981-2014 & $\begin{array}{l}\text { The ratio of liquid liabilities to GDP } \\
\text { measures the size of the financial } \\
\text { intermediary system relative to the size } \\
\text { of the Nigerian economy and the ability } \\
\text { of financial intermediaries to meet } \\
\text { unanticipated demand to withdraw } \\
\text { deposits by customers (Naceur et al., } \\
2014 \text { ), }\end{array}$ & \begin{tabular}{|lr} 
Beck, Demirguc-Kunt, & Levine, \\
$\&$ & \\
2000.Financial & \\
development & and \\
structure data set (2014 & \\
version)
\end{tabular} \\
\hline $\begin{array}{|lr|}\text { Real } & \text { Gross } \\
\text { domestic } & \text { product } \\
(\text { RGDP) } & \\
\text { We expect }(+)\end{array}$ & $1981-2014$ & $\begin{array}{l}\text { Real gross domestic product (GDP) } \\
\text { is an inflation-adjusted measure that } \\
\text { reflects the value of all goods and it } \\
\text { captures the demand and supply of } \\
\text { financial activities in the economy. }\end{array}$ & $\begin{array}{lr}\text { World } & \text { bank } \\
\text { Development } & \\
\text { Indicators } & \text { (World } \\
\text { Bank) } & \end{array}$ \\
\hline $\begin{array}{|lr|}\text { Deposit } & \text { Money } \\
\text { Bank } & \text { Asset } \\
(\text { dbgdp) } & \\
\end{array}$ & 1981-2014 & $\begin{array}{l}\text { The ratio of deposit money bank assets } \\
\text { to GDP captures the overall size of the } \\
\text { banking sector relative to the size of the } \\
\text { Nigerian economy. }\end{array}$ & \begin{tabular}{|lr} 
Beck, Demirguc-Kunt, \\
$\&$ & Levine, \\
2000. Financial & \\
development & and \\
structure data set & (2014 \\
version)
\end{tabular} \\
\hline 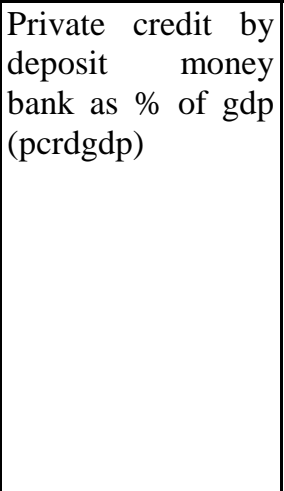 & $1981-2014$ & $\begin{array}{l}\text { credit to the private sector by deposit } \\
\text { money banks (\% GDP) which excludes } \\
\text { credit issued to the public sector } \\
\text { (government, government agencies and } \\
\text { public enterprises as well as the credit } \\
\text { issued by the monetary authority), The } \\
\text { volume of domestic credit to the private } \\
\text { sector by deposit money banks relative } \\
\text { to the size of the Nigerian economy } \\
\text { measures the contribution of financial } \\
\text { intermediaries to private sector } \\
\text { activities through intermediation. }\end{array}$ & $\begin{array}{l}\text { Beck, Demirguc-Kunt, } \\
\& \quad \text { Levine, 2000. } \\
\text { Financial development } \\
\text { and structure data set } \\
\text { (2014 version) }\end{array}$ \\
\hline $\begin{array}{l}\text { Government } \\
\text { expenditure \% gdp } \\
\text { (govgdp) }\end{array}$ & \begin{tabular}{|l|}
$1981-2014$ \\
\end{tabular} & $\begin{array}{l}\text { This variable is included in the study to } \\
\text { control for the influence of other } \\
\text { components of the Nigerian macro } \\
\text { economy. }\end{array}$ & CBN, 2014. \\
\hline
\end{tabular}

Source: Author's Design.

Copyright (C) International Association of African Researchers and Reviewers, 2006-2017: www. afrrevjo.net. 


\section{Model specification}

Following studies finance-growth literature, it is plausible to form the long-run relationship between llgdp,dbgdp,pcrdgdp, govxgdp and rgdpcin linear form, with a view of testing the relevant hypothesis as stated in section as follows:

$r g d p c=f(l l g d p, d b g d p, p c r d g d p, g o v x g d p)$

The above equation can be written in econometric model and in their respective natural $\log$ form as thus; The above models can be re-written as econometric model for this study as thus:

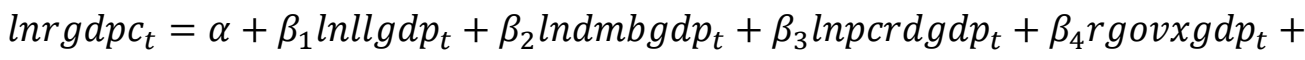
$\varepsilon_{t}$

In the production function $\ln r g d p c_{t}$ is the natural $\log$ of income per capita,, $\ln l l g d p_{t}$

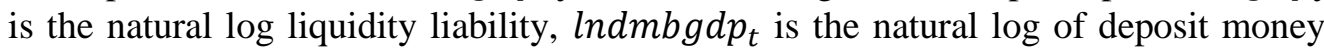
bank, $\operatorname{lnp} c r d g d p_{t}$ is natural log private credit to deposit money bank, lngovex $g d p_{t}$ is the natural log of government expenditure $\alpha$ is the intercept, $\beta_{1}$ to $\beta_{4}$ are the elasticities with respect to change to income per capita... $\varepsilon_{t}$ is the stochastic error term. In line the market fundamentals, we expect all the financial development to have positive signs. However, some studies like Naceur et el (2014) found these variables to have negatively effect in economic growth especially oil exporting countries.

\section{Estimation Procedure}

\section{Unit root Test}

In time series analysis, before running the co integration test the variables must be tested for stationary. For this purpose, we use the conventional ADF tests. Therefore, before applying this test, we determine the order of integration of all variables using unit root tests by testing for null hypothesis $H_{o}: \beta=0$ (i.e. $\beta$ has a unit root), and the alternative hypothesis is $H_{1}: \beta<0$. This is to ensure that all the variables are integrated at I(1) to avoid spurious result.

\section{Johansen Co integration}

This study adopted a dynamic vector autoregressive regression (VAR) which explores co-integration. The essence is to capture the causal dynamics relationship between monetary policy and exchange rate, and at the same time to observe the long run and short dynamics. For instance, given a VAR with possible long run co integration amongst a set of variables.

Therefore, we start with the Johansen co-integration equation which starts with the vector auto regression (VAR) of order $p$ is given by:

$y_{t}=\mu+A_{1} y_{t-1}+\ldots \ldots . .+A_{p} y_{t-P}+\varepsilon_{t}$

Copyright (C) International Association of African Researchers and Reviewers, 2006-2017: www. afrrevjo.net.

Indexed African Journals Online: www.ajol.info 
Where $y_{t}$ is a $(n \times 1)$ vector of variables under consideration in log form that are integrated at order one-commonly denoted $1(1), n=4 A_{P}$ are the parameters to be estimated, $\varepsilon_{t}$ are the random errors. This (VAR) can be re-written as;

$\Delta y_{t}=\mu+\prod y_{t-1}+\sum_{i=1}^{p=1} \Gamma_{i} \Delta y_{t-i}+\varepsilon_{t}$

Where, $\Pi=\sum_{i=1}^{p} A_{i}-1$ and $\Gamma_{i}=-\sum_{j=i+1}^{p} A_{j}$

The above equation is a pure Johansen Co integration test. Gregory and Hansen (1996) noted that the Johansen test is a test for co-integration that allows for more than one co-integration relationship. If the coefficient matrix $\Pi$ has reduced $\operatorname{rank} r<n$, then there exist $n \times r$ matrices of $\alpha$ and $\beta$ each with rank $r$ such that

$\Pi=\alpha \beta^{\prime}$

Where $r$ is the number of co-integrating relationship, the element is $\alpha$ is known as the adjustment parameters in the vector error correction model and each column of $\beta$ is a co integrating vector. It can be shown that, for a given $r$, the maximum likelihood estimator of $\beta$ define the combination of $y_{t-1}$ that yield the $r$ largest canonical correlations of $\Delta y$ with $y_{t-1}$ after correcting for lagged differences and deterministic variables when present. The two different likelihood ratio test of significance of these canonical correlations are the trace test and maximum eigenvalue test, shown in equation 5 and 6 respectively below

$\lambda_{\text {trace }}(r)=-T \sum_{i=r+1}^{n} \ln \left(1-\widehat{\lambda_{l}}\right)$

and

$\lambda_{\max }(r, r+1)=-T \ln \left(1-\hat{\lambda}_{r+1}\right)$

Here, $\mathrm{T}$ is the sample size and $\hat{\lambda}_{i}$ is the $i^{\text {th }}$ ordered eigenvalue from the $\Pi$ matrix in equation 3 or largest canonical correlation. The trace tests the null hypothesis that the number of $r$ co-integrating vector against the alternative hypothesis of $n$ co-integrating vector where $n$ the number of endogenous variables is. The maximum eigenvalue tests the null hypothesis that there are $r$ co integrating vectors against an alternative of $r+$ 1 (see Brooks 2002).

\section{Vector Error Correction Model (VECM) and Granger Causality Test}

After testing for co-integration among the variables, the long run coefficients of the variables are the estimated. This study uses the Engle and Granger (1987) test augmented by the error correction term for detecting the direction of causality between the variables. The advantage of using vector error correction (VECM) modelling framework in testing for causality is that it allows for the testing of short-run causality through the lagged differenced explanatory variables and for long-run causality through

Copyright (C) International Association of African Researchers and Reviewers, 2006-2017: www.afrrevjo.net.

Indexed African Journals Online: www.ajol.info 
the lagged ECM term. A statistically significant $E C M_{t-1}$ term represents the long-run causality running from the explanatory variables to the dependent variable. For instance, if two variables are non-stationary, but become stationary after first differencing and are co integrated, the $p$ th-order vector error correction model for the Granger causality test assumes the following equation:

$$
\begin{gathered}
\Delta \ln X_{t}=\alpha_{10}+\sum_{i=1}^{p_{11}} \theta_{11 i} \Delta \ln X_{t-1}+\sum_{i=1}^{p_{12}} \partial_{12 j} \Delta \ln Y_{t-j}+\delta_{13} E C M_{t-1} \\
+u_{1 t} \\
\Delta \ln Y_{t}=\alpha_{20}+\sum_{i=1}^{p_{21}} \theta_{21 i} \Delta \ln X_{t-1}+\sum_{i=1}^{p_{22}} \partial_{22 j} \Delta \ln Y_{t-j}+\delta_{23} E C M_{t-1} \\
+u_{2 t}
\end{gathered}
$$

Where $\theta$ and $\boldsymbol{\partial}$ are the regression coefficients, $u_{t}$ is error term and $p$ is lag order of $x$ and $y$ Table 6 indicates that the optimal lag order based on the Akaike information criteria (AIC) is 2 . The presence of short-run and long-run causality can be tested. If the estimated coefficients of $y$ in Eq. 2 is statistically significant, then that indicates that the past information of $y$ (e.g economic growth) has a statistically significant power to influence $x$ (Financial development) suggesting that $y$ Granger causes $\mathrm{x}$ in the shortrun. The long-run causality can be found by testing the significance of the estimated coefficient of $E C M_{t-1}\left(\delta_{23}\right) . E C M_{t-1}$ is the error correction term obtained from the co integration model. The error coefficients $\delta_{23}$ indicate the rate at which the co integration model corrects its previous period's disequilibrium or speed of adjustment to restore the long run equilibrium relationship. A negative and significant $e c m_{t-1}$ coefficient implies that any short run movement between the dependant and explanatory variables will converge back to the long run relationship. Indeed, it recovers any long-run information that is partially lost in the system with differenced coefficient. So, that this terms are needed to gain model stability in the long run. Narayan and Smyths (2008).

\section{Data Presentation and Analysis}

Our analysis here divided into namely; descriptive statistics and empirical analysis

\section{Empirical Analysis}

\section{Stationary test}

Copyright (C) International Association of African Researchers and Reviewers, 2006-2017:

$$
\text { www.afrrevjo.net. }
$$


Table 2: Unit root test

\begin{tabular}{llllll}
\hline \multirow{5}{*}{ Variables } & \multicolumn{2}{l}{ Augmented Dickey Fuller (ADF) } \\
& Levels & \multicolumn{3}{c}{ 1st Diff } & Order of Integration \\
\hline Lngdp & t-Stat. & P-value & t-Stat. & P-value & I(1) \\
Lndbagdp & 1.117166 & 0.9968 & -3.4857 & 0.0153 & $\mathrm{I}(1)$ \\
Lnllgdp & -2.48897 & 0.1274 & -3.80848 & 0.007 & $\mathrm{I}(1)$ \\
Lnpcrd & -2.75774 & 0.2224 & -4.28398 & 0.01 & $\mathrm{I}(1)$ \\
Lngovexp & -0.37095 & 0.5431 & -4.49063 & 0.0013 & $\mathrm{I}(1)$ \\
**level of significance at 5\% ***level of significant at $1 \%$ & $\mathrm{I}(1)$
\end{tabular}

Source: Various computation from eview9

The stationary tests were performed first in levels and then in first difference to establish the presence of unit roots and the order of integration in all the variables. The results of the ADF stationary tests for each variable show that the tests fail to reject the presence of unit root for data series in level, indicating that these variables are nonstationary in levels. The first difference results show that these variables are stationary at $1 \%$ and $5 \%$ significance level (integrated of order one 1(1)). As mentioned in the preceding sections, a linear combination of I (1) series could be I (0) if the series are co integrated. We thus proceed to test for co integration of the time series.

\section{Multivariate Johansen Cointegration-Maximum Likelihood Framework}

Table 3: Johansen co-integration result

\begin{tabular}{|c|c|c|c|c|}
\hline Hypothesis & Trace Stat & $\begin{array}{l}5 \% \text { critical } \\
\text { value }\end{array}$ & $\begin{array}{l}\text { Max.Engen } \\
\text { Value }\end{array}$ & $\begin{array}{l}5 \% \text { critical } \\
\text { value }\end{array}$ \\
\hline \multicolumn{5}{|c|}{ rgdpc $=f($ dbagdp,llgdp,pcrd, govexp) } \\
\hline$r=0$ & $86.641 * *$ & 69.81889 & $40.05 * *$ & 33.87687 \\
\hline $\mathrm{r} \leq 1$ & 46.59165 & 47.85613 & 28.92354 & 27.58434 \\
\hline $\mathrm{r} \leq 2$ & 17.6681 & 29.79707 & 9.46878 & 21.13162 \\
\hline$r \leq 3$ & 8.199323 & 15.49471 & 8.129614 & 14.2646 \\
\hline $\mathrm{r} \leq 4$ & 0.069709 & 3.841466 & 0.069709 & 3.841466 \\
\hline
\end{tabular}

*level of significance at $10 \% * *$ level of significance at $5 \% * * *$ level significance at $1 \%$

Source: various computation from eview9

The result of the co integration test, based on the Johnson co integration approach are presented in table 5. The aim is to establish whether long-run relationship exists among the variables of interest. The first step was to establish the lag using akaike information

Copyright (C) International Association of African Researchers and Reviewers, 2006-2017:

$$
\text { www.afrevjo.net. }
$$

Indexed African Journals Online: www.ajol.info 
criterion. Then, cointegration was tested on the long run relationship between the dependent variable (real gdpc) and independent variables (financial development variables) while controlling for the influence government expenditure. The table indicates that the test failed to accept the null hypothesis of no cointegration at 5\% level of significance. Both the trace and Maximum Eigen value suggest that there is a common stochastic trend and as such the number of free random walks has been reduced by one. This implies that an equilibrium relationship exists among the co integrating variables. In addition, no matter the fluctuation in the short run, these variables have the tendency to return to this equilibrium path in the long run.

Normalised cointegartion Equation:

$\Delta r g d p c=-20.94-0.972 d m b-0.5057 l l+2.125 p c r d-1.102 g o v e x p+\varepsilon_{t}$

$$
[1.9768] \quad[2.0068] \quad[-3.805] \quad[6.3062]
$$

Equation 11 represents the normalised co integration equation, while the values in the bracket are the t-statistics. The equation gives the long run impact of financial development on economic growth captured by various variables deposit money bank, and liquidity liability which contributed negatively significant to economic growth in Nigeria while and private credit by deposit money bank has a positive and significant impact on the real gdpc. Indeed, all the variables do not agreement with the apriori expectations, except PCRD and the figures in bracket are the t-statistics.

The study found the coefficient of DMB to be negative and statistically significant at $10 \%$ level. With coefficient of $0.9872,1 \%$ decrease in deposit money bank will cause the overall economic growth increase by $0.9872 \%$ in the long run. Also, the study found the coefficient of liquidity liability to be negative and statistically significant at $5 \%$ level. With coefficient of $0.5057,1 \%$ decrease in liquidity liability will cause the overall economic growth increase by $0.5057 \%$ in the long run. Furthermore, study found the coefficient of PCRD to be positive and statistically significant at 5\% level. With coefficient of $2.125,1 \%$ decrease in PCRD will cause the overall economic growth increase by $2.125 \%$ in the long run. Controlling for the influence of government expenditure, the study found the coefficient of government expenditure to be negative and statistically significant at $10 \%$ level. With coefficient of $1.12,1 \%$ decrease in government expenditure will cause the overall economic growth increase by $1.12 \%$ in the long run.

Since the presence of co integration among variables means that causality must run from at least one direction, therefore, we apply error correction model, in company of variance decomposition and impulse response for more robust analysis

Copyright (C) International Association of African Researchers and Reviewers, 2006-2017: www.afrrevjo.net.

Indexed African Journals Online: www.ajol.info 


\section{Causality Test}

Table 4: Long run and short run causality estimates.

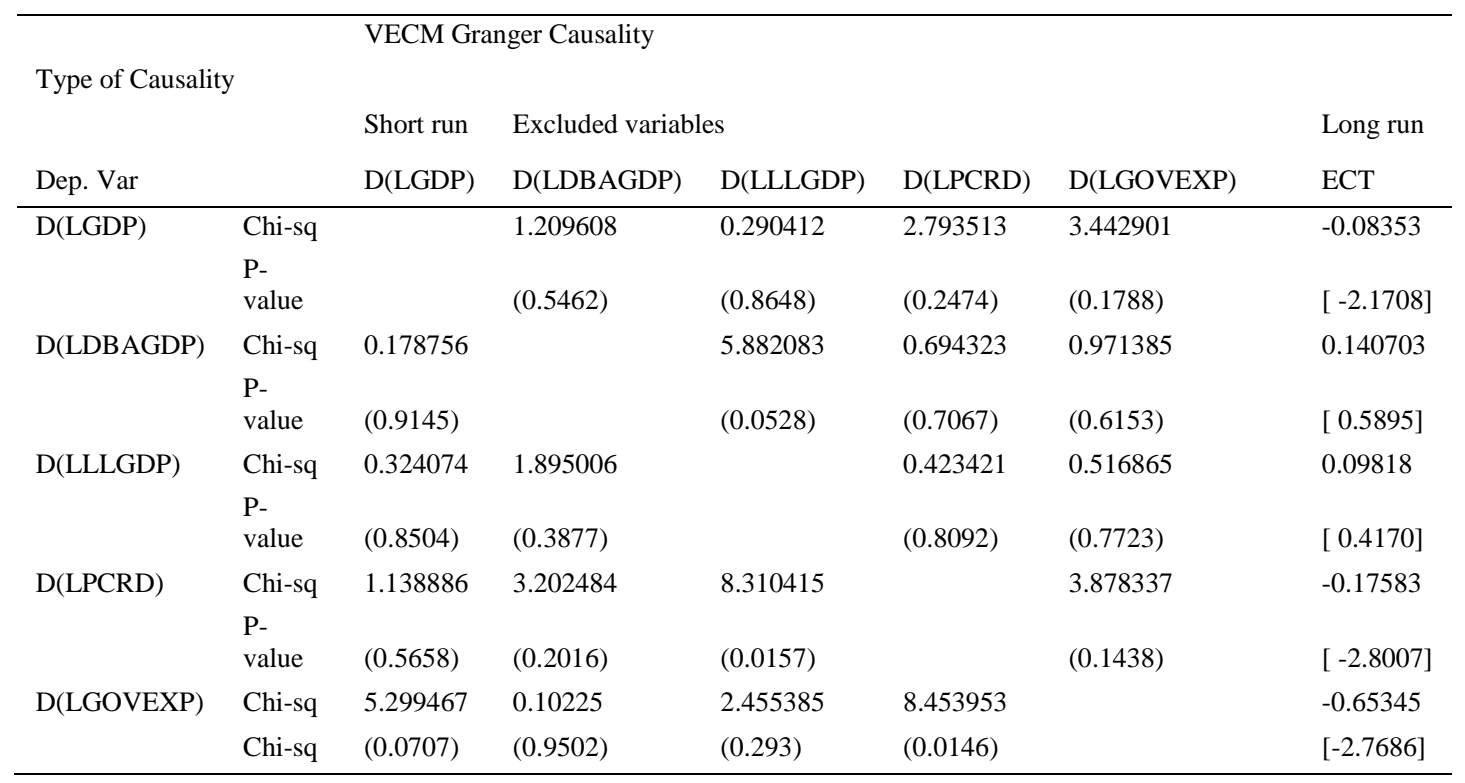

Note: *, **, and *** indicate significance at $10 \%, 5 \%$ and $1 \%$, respectively t-statistics in [ ] and P-values in ( )

Source: various computations from eview9

This study used the Granger causality test augmented by the error correction term for detecting the direction of causality between the variables. The optimal lag order selected based on the Akaike information Criteria (AIC) is 2. The VECM Granger causality divides causality results into long run as well as the short run. The results regarding the VECM Granger causality test are reported in Table 6. The empirical results suggest that $\mathrm{ECT}_{\mathrm{t}-1}$ has negative sign and statistical significant in economic growth, PCRD and govexp. This implies that there is bidirectional causality between economic growth, PCRD and govexprespectively in the long run. Bidirectional causality between economic growth, PCRD and govexp indicate that they are complementary.

A number of causal interactions exist in the short run. The results in Table 4 show a unidirectional causality running from government expenditure to economic growth, from economic growth to government expenditure. There are no other causalities reported in table 6 indicating that financial activities in Nigeria is yet to be exploited. In sum, the coefficients of ECM (-1) in table 4 is negative and significant at $5 \%$ level.

Copyright (C) International Association of African Researchers and Reviewers, 2006-2017: www.afrrevjo.net. 
The coefficients suggest that approximately $8 \%$ of the short-run disequilibrium is corrected in the long run within one-year period.

\section{Discussion of Findings}

The endogenous growth models suggest that financial development influences economic growth through a number of channels particularly through investment, saving, and productivity. In agreement to this, we examined financial development and economic growth using various channels. Using the individual financial indicators, the results are as follows; The Trace and Max Engen statistics are significant at 5\% level suggesting that there is a common stochastic trend and as such the number of free random walks has been reduced by one. Therefore, real gdpc and financial development variables have at least one common stochastic trend driving the relationship between them. The idea here is that the null hypothesis of no long run significant relationship of economic growth and financial development variables is rejected.

In the second hypothesis, VECM granger causality test augmented by the error correction term was used to establish the direction of causality between economic growth and financial development variables. The result revealed that there is long run unidirectional causality running from economic growth to liquid liability at $5 \%$ level of significance. This result followed the findings of King and Levine, 1993 and Levine, Zervos, 1998 who posited that there was evidence of causality running from economic growth to the development of financial intermediaries. Whereas, in the short run, causalities do not run from any direction. The intuition here is that real gdpc causes liquid liability in Nigeria. Hence, we reject the null hypothesis of no causal significant relationship between liquid liability and real gdpc in Nigeria.

The third hypothesis centred on causal relationship between the deposit money bank and economic growth in Nigeria using augmented error correction term. Our result revealed that there is long run unidirectional causality running economic growth and deposit money bank at $5 \%$ level of significance as expected. We also found that change in deposit money bank has little significant influence on real gdpc, especially at long. Therefore, we reject the null hypothesis of no causal significant relationship between deposit money bank and real gdpc in long run and vice versa for the short run.

Turning to Hypothesis 4, our results suggested that $\mathrm{ecm}_{\mathrm{t}-1}$ has negative sign and statistical significant in the long run indicating that causality is running from real gdpc to PCRD at 5\% level of significant. There is also, a noticeable causality running PCRD to economic growth in the long run. It means that the presence of bi-directional causality hypothesis, indicating the combination of supply-leading and demand following hypotheses. This result is in consistence with the finding from (Greenwood \& Jovanovic, 1990; Berthelemy \& Vardoulakis, 1996; Blackburn \& Hung, 1998; and Harrison) who postulated that financial development gradually induces economic growth and this, in turn, causes feedback and induces further financial development. It

Copyright (C) International Association of African Researchers and Reviewers, 2006-2017: www. afrrevjo.net.

Indexed African Journals Online: www.ajol.info 
is also consistent with endogenous growth models as explained by Murind and Eng (1991), Luintel and Khan (1999) and (Kar and Pentecost 2000). Therefore, we reject the null hypothesis that there is no causal significant relationship between private sector credit and economic growth in Nigeria

\section{Policy Recommendations}

In Nigeria, for the financial system to clearly promote economic growth, monetary authorities must ensure that banks provide necessary funds to the real sector of the economy. At present, there is a weak link between the real sector and the financial system, an indication that the majority of banks' loans are channelled to unproductive sector of the economy. Monetary authorities therefore must pursue appropriate policies that will increase the level of financial intermediation, achieve positive interest rate and increase the level of investment.

\section{References}

Acaravci, S. K., Ozturk, I., \& Acaravci, A. (2009). Financial development and economic growth: literature survey and empirical evidence from sub-Saharan African countries. SAJEMS NS, 12(1).

Adam, M. A. (2011). Financial openness induced poverty reduction. The International Journal Economics and Finance,5(1), 75-86.

Ang, J. B. (2007). Financial development and economic development in Malaysia. Asian Business and Economics Research Unit, Discussion Paper 42.

Atje, R. \& Boyan, J. (1993). Stock markets and development. European Economic Review 37(2/3), pp. 632- 640.

Azege, M. (2004). The impact of financial intermediation on economic growth: The Nigerian perspective. Lagos State University.

Beck, T., Demirgüç-Kunt, A. \& Levine, R. (2000). A new database on financial development and structure. World Bank Economic Review 14, 597-605.

Bencivenga, V., Smith, B. \& Starr, R., (1996). Equity markets, transaction costs and capital accumulation: An illustration. The World Bank Economic Review, 10(2): 241-265.

Blackburn, K. \& Hung, V. T. Y. (1998). A theory of growth, financial development and trade. Economica, 65, 107-124.

CBN (2014). Central Bank of Nigerian economic and financial review.

Darrat A. F. (1999). Are financial development and economic growth causally related? Another look at the Evidence. International Economic Journal 19 Volume 13, Number 319-35.

Copyright (C) International Association of African Researchers and Reviewers, 2006-2017:

$$
\text { www.afrrevjo.net. }
$$

Indexed African Journals Online: www.ajol.info 
De-Long, J. B., Shleifer, A., Summers, L. H. \& Waldmann, R. J. (1989). The size and incidence of the losses from noise trading. Journal of Finance, 44(3): 681696.

Demeriades, P. O. \& Hussein, K. A. (1996). Does financial development cause economic growth? Time-series evidence from 16 countries. Journal of Development Economic, pp. 387-411.

Devereux, M. B. \& Gregor, W. S. (1994). International risk sharing and economic growth. International Economic Review, 35(4):535-550.

Diaz-Alejandro, C. (1985). Goodbye financial repression, Hello financial crash. Journal of Development Economics, September/October, 1-24.

Engle, R. F. \& Granger, C. W. J. (1987). Co-integration correction: Representation, estimation and testing. Econometrica 55: 251-276.

Erdal, G., Okan, V. Ş. \& Behiye, T. (2007). Financial development and economic growth: Evidence from Northern Cyprus. International Research Journal of Finance and Economics, Issue 8.

Erthelemy, J. C. \& Varoudakis, A. (1996). Economic growth, convergence clubs, and the role of financial development. Oxford Economic Papers, 48, 300-328.

Fry, M. J. (1978). Money and capital or financial development in economic development? Journal of Money, Credit and Banking, November, 464-475

Garcia, V. F. \& Liu, L. (1999). Macroeconomic determinants of stock market development. Journal of Applied Economics, II, 29-59.

Gazdar K. \& Cherif, M. (2014). The quality of institutions and financial development in many Countries: An Empirical Investigation. Risk Governance \& Control: Financial Markets \& Institutions, Volume 4, Issue 4, 2014,

Goldsmith, R. W. (1969). Financial structure and development. New Haven: Yale University Press.

Granger, C. W. J. \& Newbold, P. (1974). Spurious in econometrics. Journal of Econometrics 2 (2): 111-120.

Greenwood \& Jovanovic, B. (1990). Financial development, growth, and the distribution of income. Journal of Political Economy, 98, 1076-1107.

Gurley J. G. \& Shaw, E. S. (1955). Financial aspects of economic development. American Economic Review, 45:515-538.

Hicks, J. A. (1969). A Theory of Economic History, Oxford: Clarendon Press.

Ireland, P. N. (1994). Money and growth: An alternative approach. American Economic

Copyright (C) International Association of African Researchers and Reviewers, 2006-2017:

www.afrrevjo.net.

Indexed African Journals Online: www.ajol.info 
Review, March, pp.47-65.

Johansen, S. (1988). Statistical analysis of co-vectors. Journal of Economic Dynamics and Integrating Control, 12: pp. 231-54.

Johansen, S. (1995). Likelihood-based inference in vector autoregressive models and cultural co-integrated, (1988, 1991). New York. Johansen Press.

Johansen, S., Juselius, K. (1990). Maximum likelihood estimation and inference on co-integration - with applications to the demand for money. Oxford Bulletin of Economics and Statistics, 52, pp.169-210.

Kargbo, A. A. (2015). A situational analysis of financial development in low, middle and high income economies. International Journal of Business Management and Economic Research (IJBMER), Vol 6(2),2015,143-157

Kaufmann, D., Kraay, A. \& Zoido-Lobaton. (1999). Governance matters. World Bank Policy Research Working Paper $N^{\circ} 2196$.

Knack S. \& Keefer, P. (1995). Institutions and economic performance: Cross-country tests using alternative institutional measures. Economics and Politics 7(3), 207-227.

Law, S. H. \& Habibullah, M. S. (2009). The determinants of financial development: Institutions, openness and financial liberalization. South African Journal of Economics, 77(1), 45-58.

Levine R. \& Sara Z. (1998). Stock markets, banks and economic growth. World Bank Policy. Research Working Paper, No.1690.

Levine R. \& Sara, Z. (1996). Stock market development and long run growth. Vol. 10, No. 2. [13].

Levine R. (1991). Stock markets, growth and tax policy. Journal of Finance 46(4): 1445-1465.

Lucas, R. E. (1988). On the mechanics of economic development. Journal of Monetary Economics, 22, 3-42.

McKinnon, R. (1973). Money and capital in economic development. Washington, D.C.: Brookings Institution.

Nzotta, S. M. \& Okereke, E. J. (2009). Financial development and economic development in Nigeria: An empirical investigation. African Journal of Accounting, Economics, Finance and Banking Research, Vol. 5(5): 52-66

Obstfeld, M. (1994). Risk-taking, global diversification, and growth. The American Economic Review, Vol. 84, No. 5. pp.1310-1329.

Copyright (C) International Association of African Researchers and Reviewers, 2006-2017: www.afrevjo.net.

Indexed African Journals Online: www.ajol.info 
Odhiambho, N. M. (2004). Financial development and economic growth in South Africa. Department of Economics, University of Fort Hare, South Africa.

Pagano, M. (1993). Financial markets and growth: An overview. European Economic Review 37, pp. 613-622.

Rajan, R., \& Zingales, L. (2003). The greats reversals: The politics of financial development in the twentieth century. Journal of Financial Economics, 69(1), 5-50.

Robinson, J. (1952). The rate of interest and other essays. London: Macmillan.

Schumpeter, J. A. (1911). The theory of economic development. Oxford: Oxford University Press.

Shaw, E. (1973). Financial development in economic development. Oxford: Oxford University Press.

Shittu, A. I. (2012). Financial intermediation and economic growth in Nigeria. British Journal of Arts and Social Sciences, Vol.4 No.2.

Singh, A. (1997). Stock markets, financial liberalization and economic development. Economic Journal 107, pp. 771-782.

Stern, N. (1989). The economics of development: A survey. Economic Journal, 99, 597-685.

Tokunbo S. O. (2000). Does stock market promote economic growth in Nigeria? Thesis, University of Ibadan, Ibadan.

Torruam, J. T., Chiawa, M. A. \& Abur, C. C. (2013). Financial development and economic growth in Nigeria: An application of co integration and causality analysis. 3rd International Conference on Intelligent Computational Systems

Umar, B. N. (2010). Financial development, economic growth and stock market volatility: Evidence from Nigeria and South Africa. JUP Journal of Financial Economics; volume VII, Pg 37 - 58.

Unalmiş, D. (2002). The causality between financial development and economic growth. The case of Turkey. Central Bank of the Republic of Turkey: Research Department, 06100, Ankara.

Valverde, S. C., del Paso, R. L. \& Fernandez, F. R. (2004). Banks, financial innovations and regional growth, economics. University of Granada, Spain: Department of Economics.

Wadud, M. A. (2005). Financial development and economic growth: A co-integration and ECM approach for South Asian countries, Paper presented at

Copyright (C) International Association of African Researchers and Reviewers, 2006-2017: www.afrrevjo.net.

Indexed African Journals Online: www.ajol.info 
International Conference of the Asian Law and Economics Association at Seoul National University, South Korea on 24-25 June.

Waqabaca, C. (2004). Financial development and economic growth in Fiji. Economics Department, Reserve Bank of Fiji, Working Paper No 03.

World Bank (2014). World development report.

Yartey, C. A. (2008). The determinants of stock market development in emerging economies: Is South Africa different? IMF Working Paper. 